\title{
Opening Open Universities: The Canadian Experience
}

\author{
J.S. DANIEL and W.A.S. SMITH*
}

\begin{abstract}
This article examines, from an administrative/management perspective, the two open universities which have been created in Canada in the 1970's, Athabasca University in Alberta and the Télé-université in Québec. A study of the initial planning reveals that effective planning requires balanced attention to means and ends. The new management structures required for this type of institution, coupled with the climate of acute uncertainty in which it operates in the early days, require particularly able and committed leadership. That both institutions have been rather successful argues for the importance of the open university concept itself.
\end{abstract}

\section{RÉSUMÉ \\ Pour ouvrir les "universités ouvertes: \\ l'expérience canadienne}

Le présent article étudie, d'une perspective de l'administration et de la gestion, les deux "universités ouvertes" créées au Canada au cours des années 70 - à savoir - Athabaska University en Alberta et la Télé-université au Québec. Une étude de la planification initiale révèle que, pour procéder de façon efficace, il faut accorder une attention equilibrée aux moyens et aux fins. Les nouvelles-structures de gestion requises pour ce genre d'institution, ainsi que le climat d'incertitude profonde qui marque leurs débuts, exigent la présence des responsables compétents et engagés. Le fait que les deux institutions ont été plus ou moinx couronnées de succès est un témoignage de l'importance du concept en soi de "l'université ouverte".

\section{Introduction}

The decade of the sixties witnessed enormous growth of existing universities and the creation of many new campuses in the countries of the developed world. However, by 1970 a new type of 'open' university was emerging and many of the new institutions 
which have been created since that date have been of this type. Although the diversity of these open universities is greater than among conventional campus-based institutions they all share two important features. They are designed to serve working adults, usually without any academic prerequisites for entry, and they involve the delivery of instruction at a distance. Best known of these new institutions is the Open University of the U.K., which has identified some 29 other universities around the world which implement the open university concept ${ }^{1}$ in various ways. For most of these universities, adult offcampus students constitute the sole or primary clientele and it is on such institutions that this article concentrates.

Although many campus-based institutions are introducing elements of the open university ideal into their programming and some universities, notably in Australia and at Memorial University, Newfoundland, Canada, have successfully combined internal and external programs for many years, Perry ${ }^{2}$ suggests that, in order to flourish, an open university operation requires a high degree of institutional autonomy. This is because an open university, whilst it may share with other universities the fundamental mission of teaching, research and public service, undertakes this mission in an entirely different manner. The new teaching/learning system on which an open university is based has repercussions on every other aspect of the operation, from goverance, management and leadership to the work of the faculty and the design of physical plant.

Almost every aspect of an open university operation makes a fascinating comparison with the conventional university and Perry's book ${ }^{2}$ on the development of the U.K. Open University provides an absorbing account of the genesis and growth of a huge and highly successful institution.

This article is based on the two open universities which have been created in Canada in the 1970's, Athabasca University in Alberta and the Télé-université in Québec. Although much could be written about the contrasts between the programs, instructional systems and production methods of these institutions this paper will concentrate on their development from an administrative/management standpoint. We believe that the lessons which can be drawn from the growth of Canada's newest universities are of value to all those concerned with the management of higher education.

After describing the origins of the two institutions we shall use their brief history to draw conclusions about the planning process. Examination of governance will reveal the determing influence of the external environment and a study of the management of the two universities will show that academic departments are not the key organizational unit in this type of institution. Leadership has played a particularly vital role in each case, partly because of the high degree of uncertainty accompanying the development of these novel institutions. Finally it will be demonstrated that, despite their erratic development, both institutions have had considerable success with students, a success which supports the importance of the open university concept itself.

\section{Origins}

Canada is a confederation of ten provinces which have exclusive jurisdiction in educational matters. Alberta, in Western Canada, contains nearly two million people, overwhelmingly 
English-speaking, and is currently the richest province as result of its considerable reserves of oil and gas. Quebec is Canada's second largest province. Five million of its population of six million are French-speaking and they represent the bulk of the Francophones in the country as a whole.

The development of higher education in Alberta has proceeded steadily with the founding of the Universities of Alberta (located in Edmonton) (1907), Calgary (1945), and Lethbridge (1967). McGregor" states that, "by 1970 these institutions were sorely overtaxed with nearly 40,000 part-time and full-time students".

A major thrust of the 'quiet revolution' by which a new Liberal government attempted to transform Quebec into a modern state was a complete reform of the educational system, previously operated largely by the churches. After reorganizing the school system and creating a network of 46 colleges (CEGEPs) the University of Quebec was founded in 1978. With general campuses in Montréal, Trois Rivières, Rimouski and Chicoutimi as well as a number of more specialized institutions, this was Canada's first 'network' university. During the sixties enrollments at Quebec's universities tripled. Nevertheless, by the end of the decade only $8.6 \%$ of the 18.24 age group were attending university in Quebec compared to $14.9 \%$ in Alberta. These figures provided the basis for the creation of the University of Quebec which, although it had a majority of part-time students right from the start, was essentially a conventional multi-campus university.

Even in Alberta the universities were still under pressure as student numbers seemed to be rising inexorably. This pressure led the Alberta government, by an Order in Council dated June 1970, to establish Athabasca University. It was to be an undergraduate campusbased university located in St. Albert, just outside Edmonton, and limited to Arts, Science and Education. An Interim Governing Authority of eight persons was appointed to plan and make the University operative.

At this time the University of Quebec was already functioning. However, it was becoming clear that even this major additon to the province's higher education system did not answer all the needs, especially of part-time adult students. News from abroad contained reports of new types of universities, notably the Open University and the University Without Walls, which were designed especially for such students. Discussions began within the University of Quebec on the idea of a distant study unit, called the télé-université project, and in 1971 a task force was set up to describe how such a project might operate.

\section{Initial planning}

By April 1971 the Athabasca University Interim Governing Authority (AUIGA) published its first planning document entitled 'The Academic Concept'. Mostly devoted to a treatise on liberal education, this document saw the future student body as made of 18-21 year olds living in the Edmonton area and foresaw some problems of competition for students with the neighbouring University of Alberta. Nevertheless, it was thought that enrollments might reach 10,000 by the end of the seventies. The input-output microplanning model was described as the approach which would be used in further planning.

In August 1971 the Social Credit provincial party which had been in power for 36 years was defeated at the polls and a new Conservative government took power, promising to 
review all capital projects. That fall there was a drop in enrollments at the other universities so that "planning became less than certain in the latter half of the fiscal year" and "all physical planning relating to the Athabasca University (was) suspended indefinitely" 4 . In October 1972 the AUIGA published "Athabasca University: an experiment in practical planning" stating that the "phase from $1974-77$ will involve operating a mini-college with 250 students."

In December 1972 the government rescinded all Orders in Council concerning Athabasca University. By a new Order it established the university with a six member Authority and empowered it to undertake a pilot project on the design and delivery of multi-media university level courses to off-campus students.

In Quebec the task force on the télé-université had reported in May 1972, telling the University of Quebec (UQ) that the télé-université should address the following challenges:

- Education permanente. The heart of renewal of higher education

- Real accessibility for all.

- Social development.

- Needs of working population.

- Greater mobility of knowledge.

- Wide use of new media and techniques.

- Rethinking the learning situation.

- Taking account of people's piror life experiences.

- Reduction of unit costs

Although the tele-universite project was "rich in a thousand ways, invited daring and allowed every hope", the rather vague recommendations about the organization did not exemplify this daring. It was merely suggested that the project should not have the status of an institution (university or campus) within the UQ network but that it should be more than simply a service unit to the existing campuses. This vagueness was an attempt to avoid displeasing either the UQ President or the rectors of the existing UQ campuses. By 1972 many people within the UQ had begun to realize that the University as a whole was looking much more conventional than its founders had hoped. Some rectors feared that the novel approach of the téle-université would steal both their thunder and their students and wished to contain the project tightly. The UQ President, on the other hand, saw the télé-université as a leaven which could spread a new and modern pedagogy throughout the network.

In October 1972 the UQ Board of Governors (UQBG) established the tele-universite project as a five year programme of development and experimentation of distance education aimed at those whom "existing university services do not reach, reach with difficulty, or do not satisfy". The project would be governed by a commission, under the UQBG, composed of 9-15 members, all chosen from within the UQ after consultation with the rectors of the campuses. The UQ President would chair the commission.

A warning of problems ahead came when the Rector of the largest UQ campus (Montreal) abstained from voting on the UQBG motion to create the télé-université project and asked to have his abstention recorded. His abstention almost certainly reflected the view that, with sufficient resources, the campuses could themselves accomplish the tasks assigned to the télé-université. Hostility to any expansion of the project, whether in autonomy or influence, was a fairly consistent policy of the Montreal campus for the next four years. 


\section{Lessons}

Rational planning requires satisfactory relationships between ends and means and successful planning implies that relevant problems are actually solved. MacDonald-Ross ${ }^{6}$ has given a useful representation of the relationship between ends/means analysis and problem solving in Figure 2.

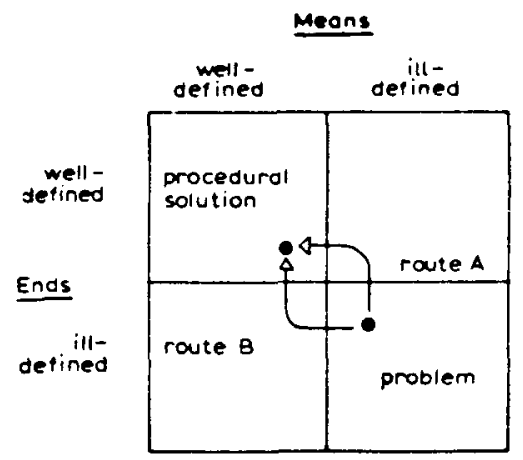

Figure 1 - The ends/means approach to problem solving. An ill-defined problem may be converted into soluble form via either of the two routes (from an idea of Brian Lewis).

When both ends and means are well-defined the problem is simply to put the right procedure into effect. Other problems start with either ends or means ill-defined in which case solution depends on resolving the ill-defined dimension. However, the most interesting and common problems have both dimensions ill-defined. The Athabasca and télé-université planners had major problems of this kind. In the academic sense, for example, it was necessary to define both the means by which courses would be delivered and the nature of the programs and credentials to be offered.

It is interesting to observe that the two groups tackled the problem in different ways. In Alberta most of the planning work went into defining means. Not only did the government decide that the first answer to an apparent excess of demand in higher education was to create a new university, but the University planners themselves also concentrated on the means (liberal education, modular colleges). This may be represented by route $\mathrm{B}$ in Figure 2.

The télé-université task force took route A and devoted their attention to classifying the definition of ends. The goal of serving the needs of working adults was explored in detail whereas the means were left vague.

In following the development of the two institutions it will be apparent that each met problems principally as a result of the dimension it had left undefined. The rather obvious prescription to state but difficult to accomplish is that the most effective planning uses a mixed strategy by alternating between definition of ends and of means or by defining both at the same time.

\section{Governance}

By the end of 1972 both Athabasca and the téle-université project had an identifiable governance structure and a clear goal statement although, in the case of Athabasca, the 
new mandate of a pilot project in distant study had been imposed by government and was diametrically opposed to what the university planners themselves had been working on for two years.

Millett ${ }^{7}$ has suggested eight areas of responsibility in which the successes or failure of governance structures can be assessed:

- Clarification of institutional purposes.

- Specification of program objectives.

- Reallocation of income resources.

- Development of sources of income.

- Management.

- Instructional program outlines.

- Issues of academic and student behavior.

- Program evaluations.

Although we may examine developments in the light of these criteria it is only fair to point out that in both projects the governing body had a much less free hand than is usual in the U.S. institutions on which Millett bases his book.

Athabasca was now a pilot project and one observer suspected that the government was "bent on making Athabasca University a particularly creative case study in institutional demise". The fact that it could be terminated by Order in Council at any time hardly gave the governing body ideal conditions in which to operate and the plaintive disclaimer in the, first calendar, "the future of Athabasca University beyond 1976 has not yet been finally settled", cannot have helped to attract students.

In the télé-université project the governance structure itself was a source of controversy for the next four years. The project's first tasks were to take over the management of a distant study, in-service training program for mathematics teachers and to offer a course on the co-operative movement to the general public. Both were successful, the co-operatives course attracting over 4000 students when it was first offered in 1974, but this very success strained the governance structure to its limit. Of the eight members of the télé-université Commission (TUC) only one, the director-general, was attached to the project. The others tended to adopt a watchdog role with the UQ President trying to hold the ring as chairman. Moreover, any decisions the TUC did manage to make had to be ratified by one or more of four different UQ committees and/or by the UQBG itself.

In June 1974, as part of a thorough reform of the UQ initiated by a new president, the governance structure of the télé-université was changed to give the project greater autonomy as the UQ campuses, although its mandate was limited to the missions given to it by the UQBG, it became usual to spell Télé-université with a capital. A reformed TUC now had the director-general in the chair and included three lay members as well as five members from UQ campuses and headquarters.

Although the UQBG voted this new status unanimously, and the new structure proved much more workable for the Télé-université, it was not the end of the story. The in-service teacher programs, in which the campuses had to work together under Télé-université management, although highly successful both operationally and instructionally ${ }^{8}$, were seen, particularly by the Montreal and Rimouski campuses, as an affront to institutional sovereignty. A decision to transfer the management of one of these two programs to UQ 
headquarters in Fall 1975 failed to resolve the issue and in May 1976 the UQ President, having been unable to achieve consensus, asked the UQBG to make a straight choice between continuing the Télé-université as an autonomous unit or closing it down completely. By 8 votes to 3 the board elected for continuation and removed from the Télé-université's mandate any reference to professional training and to joint projects with the campuses.

Although the TUC had taken a back seat and had even been instructed to suspend its meetings during the period of controversy in 1974 and 1976, one aspect of its mandate had proved to be a useful innovation, namely that it was to act as both an administrative and an academic council. The fact that the academic programs of the Télé-université continued with increasing success whilst the future of the institution itself hung in balance is in part attributable to the dual role of the TUC.

Athabasca University was to adopt a unicameral governance structure in 1976 but the pilot project stage which began in 1972 was conducted without the benefit of this concentration of power. An important role was played by the Academic Council which, to judge by the changes in programs and courses between the 1974, 1975, or 1976 calendars, charted a somewhat erratic course as the academic and instructional rhetoric of the late sixties withered in the harsher climate of the seventies.

In 1975 the Alberta government declared the Athabasca pilot project sufficiently convincing for the University to be given permanent status. However, it was not until April 1978 that, with the publication by Order in Council of the Athabasca University Regulation, this decision was made official. This Regulation replaced the previous Interim Governing Authority by a unicameral Governing Council composed of:

- Chairman (appointed by Lieutenant Governor in Council).

- President and 2 Vice Presidents.

- 1 student.

- 1 elected support staff member.

- 5 elected academic staff members (in the Regulation the term academic includes all professional staff).

- not more than 12 additional members representative of the general public appointed by the Lieutenant Governor in Council.

The novel composition and powers of this Council provide a real test of an interesting experiment in university governance. While data continues to be collected, and a more substantial period of time is required before assessments can be made with confidence, it is apparent from the experience to date that several aspects of the unicameral model. are particularly well suited to the open university. In the single governing council structure, there is no artificial division between academic or curricular decisions and administrative or more specifically, source allocation considerations. This essential feature of the unicameral governing apparatus permits the open university to remain responsive to the changing educational needs of its students and to do so with considerable flexibility as to delivery methods. In short, the essential virtue of the single council approach is that it permits a timely response to changing needs.

It is interesting that Perry ${ }^{2}$ describes the unicameral structure with some envy before explaining the role of the 600 member Senate at the U.K. Open University! 


\section{Management}

Perry $^{2}$ begins his chapter on government structure, which should be read by anyone interested in the management of open universities, by stating: "What has emerged is an extremely complex system. It surprises me that it works as well as it does, and it is very difficult indeed to describe." The same comments could be made about management in the two Canadian institutions, despite their much smaller size. Acknowledging that his conclusions are based on data from the traditional campus-based universities we cannot accept Millett's remark ${ }^{7}$ that : "I see no effective organizational arrangement for the Learning process other than the academic department." One effective arrangement which is used at both Athabasca and the Télé-universite is the course team, a group made up of academics and other professionals which is responsible for the development of a particular course. Perry ${ }^{2}$ holds that the course team is the most significant concept which open universities have introduced into the management of higher education and the team approach to course development ensures that even in small open universities the quality of instructional materials is rather high.

A key management question in both Athabasca and the Télé-université has been the reporting lines from the course team. Broadly the choice has been seen as whether course teams should relate to program directorates, having responsibility for both the development and delivery of courses in a particular program or to functional units responsible university. wide for a particular operation.

Neither extreme can be defended as ideal, which probably explains why both institutions oscillate between them. The Télé-université had, from around 1976 on, strong program directorates. However of late, as it has relinquished its in-service program for teachers and attracted over 12,000 students to its main 'Man and His Environment' program, greater stress has been placed on functional units.

At Athabasca the pendulum has swung both ways. In the early days, perhaps as a legacy of the original plan for a conventional campus university, the notion of an academic department gained a stronger hold than it ever did at the Télé-université. This was followed, in $1976 / 77$, by a move to management by the functional units of program development and program delivery. The creation of a Faculty Association in April 1977 was not unrelated to this move.

At the Télé-université a staff association, including professional, academic, and support staff, and both regular and contract employees, had been created in December 1976 as a direct result of the reorganization imposed by the UQBG after the decision to divest the Télé-université of management of the in-service programs for teachers. These involved over 2,000 students and the Télé-université had designed and staffed its administrative structure to manage these programs in addition to its own 'Man and His Environment' program. Removal of the in-service programs would have left the Télé-université management structure top heavy and increased unit costs unacceptably. To counter this problem the UQBG, in November, 1976, voted a reorganization of the Télé-université which involved the abolition of 52 positions, bringing the total number of staff down from 134 to 82 .

At the time of this reorganization there were some 1,000 course enrollments in the Télé-université's own program and the institution was told to increase this figure to over 3,000 by the end of $1976 / 77$ and to nearly 12,000 in $1977 / 78$. 
There were some, both inside and outside the Télé-université, who thought that the institution might fall at these fences. That both targets were achieved with only a momentary lull in morale not only shows the strength of the open university concept but reflects well on both staff and management.

\section{Leadership}

Millett ${ }^{7}$ remarks that: "The structures of campuswide governance developed in the 1960's were conspicuous in their studious avoidance of instruments or agents of leadership" and points out that "by the late 1970's the indispensability of presidential leadership was again rather generally acknowledged, if not always appreciated".

Open universities have contributed significantly to the trend which Millet reports. Although he would deny it the national and international success of Britain's Open University owes much to the person of Lord Perry and the role of leaders has been equally important in Canada's open universities.

Both Fernand Grenier and Tim Byrne, the first executive heads of the Télé-université and Athabasca University respectively, left senior academic and governmental positions to direct the fortunes of these new institutions. Their conviction and readiness to stake their reputations on this innovation in higher education were a vital factor in the survival of the institutions through the ensuing years.

Both Athabasca and the Télé-université have led a precarious existence right up to the present day. Van Court Hare ${ }^{9}$ has identified twelve of the most common problems encountered in implementing new systems which are: differing perceptions of objectives and constraints among those involved with the system; inappropriate effectiveness measures; badly oriented attention and awareness functions; lack of operating standards; protection of vital systems processes against danger or failure; provision for updating the system; protection of system against direct falsification or illicit interruption; personnel performance compatible with the system; capability of the system to act in response to signs of danger; bridging at the boundaries of functions, departments and components; availability of adequate resources; and choice of an efficient size for the system. We have analyzed the first years of the Télé-université in terms of these generic problems elsewhere ${ }^{10}$ and in the case of Athabasca University, Van Court Hare's problem anticipation file is equally relevant. Both the radical change in mandate imposed in 1972 and the impermanent status of a pilot project could well have spelt the collapse of the institution, for the economics of open learning are threatened by short-term commitments and small size.

An important function of leadership was to operate and adapt a rational organizational structure to achieve short term objectives in a climate of acute uncertainty and unpredictability Without suggesting the deliberate introduction of confusion, or even subjectivity, into the planning model described earlier, it is essential to underscore the special importance of flexibility and responsiveness in an open university. Such institutions have features of a production industry, not found in other universities, which require a high degree of organization. However, the energetic and often individualistic staff which are attracted to new open universities must be asked to occupy rather loosely defined functions and to reorder their priorities frequently. Only with good leadership can this occur without destructive friction. 
It would be interesting to speculate with Bennis ${ }^{11}$ on the dimentions of leadership that are required in such circumstances. Certainly it is obvious that a tolerance for ambiquity, a capacity for 'muddling through'. the ability to establish effective organizational structures and working relationships quickly (and to let them go and establish others), are some of these dimensions. Equally an essential call on leadership in the open university context, particularly in the early stages, is to create sufficient order and stability to permit the attainment of immediate objectives without creating or fostering the development of a new educational orthodoxy characterized bya defensive rigidity that could equal the rigidities and inflexibilities of the traditional academy. Administering an open university requires openness of mind - yet if staff are to be inspired to give of their best there must be no doubt about the commitment of the leadership to the essence of the open university concept.

No doubt the survival of Canada's two open universities through their infant years in a relatively hostile environment was due in part to the stimulating effect of that environment on the unusually high calibre of professional and support staff they were able to attract. Nevertheless, a large measure of credit must go to the leaders, both in the in the institutions themselves and in the controlling agencies, who were prepared to risk their careers and reputations to ensure that the open university concept was given a chance to prove itself.

\section{Current situation}

In 1978 both Athabasca and the Télé-université have achieved the institutional stability previously so conspicuously lacking. The Alberta government has published the Regulation confirming Athabasca's permanent status and the Quebec government has incorporated the Télé-université in its university funding formula whilst expressing no interest in paying for an evaluation that the University of Quebec had planned to conduct at the end of the five year experimental period originally proposed for the Télé-université.

In both cases this new institutional stability is a result of the successful implementation of the open university concept in the two provinces. There is little evidence that either the success of the U.K. Open University or the hesitancy of developments in open learning in the U.S.A. had much influence on planners in Canada. A commitment to the concept had to await the demonstration of its effectiveness in their own provinces.

A major part of this demonstration was success in attracting students. In 1977/78 some 12,000 individuals took one or more Télé-université courses making it a relatively large institution by Canadian standards. These students were distributed widely around the province and had a wide diversity of backgrounds. In general they are the sorts of adults the Télé-université was set up to serve and at this level of activity the unit costs of the institution are at least comparable to those of campus universities, even without taking capital expenditures into account.

Athabasca serves a smaller and better educated population (although the proportion of the 18-24 group in postsecondary education is now higher in Quebec than in Alberta ${ }^{12}$ ). Although it has not yet had the spectacular growth experienced by the Télé-université there is every sign that the figure of 1,800 enrollments in $1977 / 78$ will more than double in $1978 / 79$ as more courses become available. Once again, the students are broadly those 
at whom the institution was aimed, with a high proportion of women and adults in general living in rural areas.

However, the experience of both institutions suggests that the creation of an open university has useful repercussions on the educational system as a whole which go beyond the recruitment of a new type of student. Both Athabasca and the Télé-université appear to collaborate with other institutions and organizations in an unusually close way. The Télé-université first course on co-operatives involved intense interaction with the cooperative movement and more recently joint ventures have been organized with school boards, government departments and various associations. In a real sense the Télé-université has become a socio-educational movement.

Athabasca too works closely with a range of organizations in planning and delivering courses. Co-operation with the community colleges is especially strong and a link of particular interest is that with North Island College in British Columbia. This open college is one of the most fascinating educational projects in the whole of Canada and its own history bears out many of the comments we have made about the creation of open universities. By a mechanism of dual registration, which safe-guards the sovereignty of both institutions, several hundred North Island College students are taking Athabasca courses. With a few exceptions, it has not been usual for Canadian institutions to serve students across provincial boundaries in such a manner. There are encouraging signs that this new phenomenon will lead the governments, at least in Western Canada, to favour the creation of a consortium so that distance education programs can be used throughout the region. In any case, the exchange of courses between open universities appears to be increasing rapidly, both nationally and internationally.

In conclusion, it appears that the open university concept can contribute effectively to the renewal of higher education even in countries where populations are small. The new administrative challenges which open universities present will contribute to the refinement of management in higher education generally.

\section{REFERENCES}

Daniel J.S. "The open university concept." Canadian Journal of Information Science, 197.7, 2 (1), 129-138.

Perry, W. The open university, San Francisco, Jossey-Bass, 1977.

MacGregor, J.G. A history of Alberta. Edmonton, Hurtig, 1972.

Annual reports. Edmonton, Athabasca University, 1971-72 and 1973-74.

Athabasca University: An experiment in practical planning. Edmonton, Governing Authority of Athabasca University, 1972.

MacDonald-Ross, M. Behavioral objectives - a critical review. 1973, Instructional Science, 2, 1-52.

Millett, J.D. New structures of campus power: success and failures of emerging forms of institutional governance. San Francisco, Jossey-Bass, 1978.

Daniel, J.S. New models for in-service teacher training in Quebec: the PERMAMA and PERMAFRA programs. OECD/CERI Conference on Strategies for School-Focussed Support Structures for Teachers in Change and Innovation, Stockholm, October, 1976. 
Van Court Hare Jnr. "Analy sis for implementation." Systems for analysis: a diagnostic approach. New York, Harcourt Brace Jovanovich, 1967.

Daniel, J.S. \& Umbriaco, M. "The Tele-universite of the University of Quebec: analy sis for further implementation." Proceedings of the IEE Frontiers in Education Conference, 1974, 9-12

Bennis, W.G. Changing organizations. New York, McGraw-Hill, 1966.

Sheffield, E. "The National scene." Systems of Higher Education. Canada, ICED, 1978. 